\title{
Effect of cigarette smoke on the mRNA and protein expression of carcinoembryonic antigen (CEA), a possible chemoattractant for neutrophils in human bronchioloalveolar tissues
}

\author{
Akihiko Ohwada, Hideki Takahashi, Isao Nagaoka, Kazuhisa Iwabuchi, \\ Osamu Mikami, Shiro Kira
}

\begin{abstract}
Background - The concentration of carcinoembryonic antigen (CEA), known as a marker of malignant transformation and chronic inflammation, is increased in bronchoalveolar lavage fluid obtained from smokers compared with fluid from non-smokers. This study investigated the mechanism and biological significance of CEA production in the lungs of smokers by evaluating protein and mRNA expression in non-carcinomatous lung parenchymal tissues and in cell lines derived from human fetal lung.

Methods - Lung parenchymal tissue free from cancer or an inflammatory lesion was obtained from five non-smokers (four with lung cancer, one with pulmonary mycetoma), five ex-smokers (all with lung cancer except for one with mesothelioma), and 14 smokers (nine with lung cancer, five with emphysema) at surgery or necropsy. Cancer tissue was also collected simultaneously from the subjects with lung cancer. CEA protein in the tissue homogenates was measured by enzyme linked immunoassay. CEA mRNA expression in the non-carcinomatous parenchymal tissue and cancer tissue was evaluated by in situ hybridisation using CEA specific riboprobe and was semiquantitated by counting the number of silver grains per cell. CEA mRNA expression was also compared in three cell lines derived from human fetal lung (IMR-90, MRC-9, and CCD-14Br) after in vitro stimulation with medium exposed to cigarette smoke or air. Chemoattractant activity of purified CEA for neutrophils and monocytes was also studied in vitro.
\end{abstract}

Results - CEA content in non-carcinomatous lung tissue was increased in smokers with emphysema (mean (SD) $38 \cdot 0$ (9.2) $\mathbf{n g} / \mathrm{mg}$ protein) or with lung cancer $(38 \cdot 2(21 \cdot 6))$ compared with non-smokers $(11 \cdot 0(5 \cdot 4))$ or ex-smokers $(5 \cdot 9(2 \cdot 2))$. CEA mRNA expression in non-carcinomatous tissue, expressed by average number of grains per cell, was also increased in smokers with emphysema (mean (SD) $11 \cdot 2$ $(4 \cdot 1))$ or with lung cancer $(14 \cdot 0(8 \cdot 4))$ compared with non-smokers $(3 \cdot 1(0 \cdot 6))$ or exsmokers $(4 \cdot 0(1 \cdot 7))$. CEA content in carcinomatous tissues was $42 \cdot 8(37 \cdot 3)$ for nonsmokers, $38 \cdot 2(42 \cdot 4)$ ) for ex-smokers, and
59.0 (22.5) for smokers. The CEA content in carcinomatous tissue was higher than in non-carcinomatous tissue, but there was no difference between non-smokers, ex-smokers, and smokers. The numbers of grains per cell in carcinomatous tissue were higher than in non-carcinomatous tissues, but not different among nonsmokers (30.3 (3.9)), ex-smokers (38.3 $(13 \cdot 8))$, and smokers $(44 \cdot 3(5 \cdot 2))$. CEA mRNA expression in the cell lines was upregulated after the incubation with smoke-treated medium. Purified CEA was chemoattractant for neutrophils but not for monocytes in vitro.

Conclusions - mRNA and protein expression of CEA were increased in the normal lung tissue from smokers compared with non-smokers or ex-smokers. Since CEA content and mRNA expression were no different between smokers with non-small cell lung cancer and those with non-carcinomatous disease, it is unlikely that CEA expression in non-carcinomatous lung parenchymal tissue was influenced by the presence of the tumour and is consistent with the effect of smoking. This is supported by in vitro studies which show that cigarette smoke could induce CEA mRNA expression in fetal lung derived cells. In addition, CEA might play a part in recruitment of neutrophils into the lower respiratory tract.

(Thorax 1995;50:651-657)

Keywords: carcinoembryonic antigen (CEA), smoking, in situ hybridisation.

Cigarette smoking is an important risk factor for the development of chronic inflammatory lung diseases such as pulmonary emphysema and chronic bronchitis. Histopathological examination and analysis of bronchoalveolar lavage (BAL) cells have revealed increased numbers of alveolar macrophages and neutrophils in the lower respiratory tract of cigarette smokers. ${ }^{1-3}$ These findings suggest that cigarette smoking results in an accumulation of inflammatory cells in the lung. Another feature of BAL fluid obtained from smokers is a significant increase in the concentration of carcinoembryonic antigen (CEA), a cell surface glycoprotein which is also found in various malignant and normal epithelial cells including bronchoalveolar epithelial cells. ${ }^{4-9}$ Increased 
levels of CEA in epithelial lining fluid are considered to be a marker of chronic inflammatory change or malignant transformation. ${ }^{47}$ The localisation of CEA protein to type I and type II pneumocytes, and epithelial cells lining the bronchioles, bronchi, and trachea of the normal lung, has been shown by immunohistochemical studies. ${ }^{1011}$ Although several mechanisms including increased local synthesis, decreased CEA degradation, and preferential transport from serum have been proposed, it is unclear exactly how CEA accumulates in smokers' lung. ${ }^{12}$ Furthermore, the biological significance of CEA in smoker's lung remains to be elucidated.

In this study we have analysed CEA mRNA and protein expression in lung tissue obtained from smokers, ex-smokers and non-smokers. In addition, CEA mRNA expression in cell lines derived from human fetal lung was observed after exposure to cigarette smoke-treated medium. Furthermore, we evaluated the biological function of CEA as a chemoattractant for neutrophils and monocytes which accumulated in the lungs of cigarette smokers.

\section{Methods \\ SUBJECTS}

The subjects in this study were five nonsmokers (mean age 62 (15) years, two men), five ex-smokers (68 (5) years, all men), and 14 smokers (66 (6) years, all men). The background diseases of the subjects were as follows: non-smokers consisted of four with non-small cell lung cancer (NSCLC) and one with pulmonary mycetoma in a non-compromised host; ex-smokers all suffered from NSCLC except for one patient who had malignant mesothelioma; and smokers consisted of nine with NSCLC and five with pulmonary emphysema. In the patients with NSCLC the tumour size varied from $4 \mathrm{~cm}$ to $10 \mathrm{~cm}$ diameter. There was no evidence of pulmonary metastases at operation or necropsy. Ex-smokers had quit smoking at least three years before the study. The smokers were divided into two groups - those with NSCLC and those with non-carcinomatous disease - to discriminate between the effect of cigarette smoke and the presence of tumour on CEA expression.

\section{SPECIMENS}

Specimens of lung parenchymal tissue not affected by malignancy were obtained at surgery (three non-smokers, three ex-smokers, and five smokers) or necropsy (two non-smokers, two ex-smokers, and nine smokers). Particular attention was paid to avoid sampling areas involved in tumour or inflammatory lesions. To accomplish this, tissue samples were taken from a different lobe from that which contained a localised lesion at surgery or from the lung contralateral to the diseased site identified at necropsy. Furthermore, each specimen used in this study was examined by conventional staining with haematoxylin and eosin and it was confirmed that no obvious inflammatory or malignant changes were present.

We concomitantly obtained carcinomatous tissue from the primary tumours of the subjects with NSCLC (four non-smokers, five exsmokers, and nine smokers at surgery or necropsy).

For in situ hybridisation each tissue sample was embedded in OCT compound (Niles Inc, Elkhart, Indiana, USA). Cryostat cut tissue sections $(5 \mu \mathrm{m}$ thick) were mounted on glass slides previously treated with 3-aminopropyltriethoxysilane (Aldrich, Milwaukee, Wisconsin, USA), then fixed with phosphate buffered $4 \%$ paraformaldehyde. After several rinses in water the slides were stored at $-70^{\circ} \mathrm{C}$ until further processing.

CELL CULTURE AND IN VITRO STIMULATION BY CIGARETTE SMOKE-TREATED MEDIUM

The human fetal lung cell lines IMR-90, MRC9 , and $\mathrm{CCD}-14 \mathrm{Br}$ that originated from human fetal lung were provided by the Japanese Cancer Research Resources Bank (JCRB). The cells were grown in Dulbecco's modified Eagle medium (DMEM) supplemented with $2 \mathrm{mM}$ L-glutamine, non-essential amino acids, $20 \mathrm{mM}$ Hepes, and $10 \%$ heat inactivated fetal calf serum at $37^{\circ} \mathrm{C}$ in $5 \% \mathrm{CO}_{2}$. One million cells were plated in a $35 \mathrm{~mm}$ tissue culture dish (Iwaki Glass, Japan), cultured for three days, and stimulated with cigarette smoke-treated medium by the method of Hunninghake et al. ${ }^{1}$ Briefly, smoke from a cigarette or an equivalent amount of air was bubbled through $25 \mathrm{ml}$ of plain DMEM. The resultant solution was immediately filtered through a $0.22 \mu \mathrm{m}$ Millipore filter (Millipore, Bedford, Massachusetts, USA). The solution exposed to cigarette smoke or air was added to the culture medium to a final concentration of $1 \%(\mathrm{v} / \mathrm{v})$. The culture medium of each cell line was replaced with $2 \mathrm{ml}$ of the fresh medium after three hours exposure to the smoke or air treated fluid. The culture was then continued for an additional $0,3,6,9,12$ or 24 hours. At each time point the cells were harvested by treatment with $0.25 \%$ trypsin $/ 0.02 \%$ EDTA for two minutes at $37^{\circ} \mathrm{C}$. A portion of the collected cells were mounted on 3-aminopropyltriethoxysilane-coated glass slides through centrifugation at $340 \mathrm{rpm}$ for 10 minutes in a Cytopsin 2 (Shandon, Pittsburgh, Pennsylvania, USA), then fixed with $4 \%$ paraformaldehyde. The slides were stored at $-70^{\circ} \mathrm{C}$ until in situ hybridisation was performed. The remaining cells were sonicated in phosphate buffered saline to prepare for CEA assay. Triplicate experiments were performed for each cell line on three occasions at each time point.

\section{CEA ASSAY}

An aliquot of tissue specimen or culture cells was suspended in phosphate buffered saline (PBS) and disrupted by sonication with a Polytron (Kinematica AG, Lttau/Lucerne, Switzerland). After centrifugation at $15000 \mathrm{rpm}$ for five minutes the supernatant of the homogenate was subjected to CEA assay by enzyme linked immunoassay (EIA) using Enzyme-Test CEA (Boehringer Mannheim, Mannheim, Germany). Internal standards allowed the CEA concentration to be calculated. The lower limit 
of measurement was $0.5 \mathrm{ng} / \mathrm{ml}$ with this kit. CEA content was expressed in $\mathrm{ng} \mathrm{CEA} / \mathrm{mg}$ total protein. Protein concentration was determined by the method of Lowry using bovine serum albumin (BSA) as a standard. ${ }^{13}$

\section{PREPARATION OF CEA RIBOPROBES}

Partial cDNA of CEA was synthesised by reverse transcriptase-polymerase chain reaction (RT-PCR) using total RNA extracted from lung cancer tissues as a template by the method described elsewhere. ${ }^{14}$ The cDNA corresponds to $694 \mathrm{bp}$ of $3^{\prime}$-untranslated region of CEA gene. ${ }^{15-17}$ CEA specific primers used for the PCR were 5'-GGGAATTCGCAGCCCTGGTGTAGTTTCTT-3' and 5'-GCAAGCTTAGTCTGGAGCGACCACATAGG-3', which had restriction sites for EcoRI and Hind III, respectively. After double digestion with EcoRI and Hind III, the cDNA was inserted into the plasmid vector pBluescript SK(-) (Stratagene, La Jolla, California, USA) and transfected into DH $5 \alpha$ competent cells (GIBCO/BRL, Life Techologies Inc, Gaitherburg, Maryland, USA). ${ }^{18}$ The nucleotide sequence of the cDNA probe was confirmed by the dideoxy chain termination method. Sense and antisense riboprobes for in situ hybridisation were generated from the cDNA clone by $\mathrm{T} 3$ or $\mathrm{T} 7$ RNA polymerase and $\left[{ }^{35} \mathrm{~S}\right] \alpha \mathrm{UTP}(>1000 \mathrm{Ci} /$ mmol, SP6/T7 Grade, Amersham, Buckinghamshire, $\mathrm{UK}$ ) at $37^{\circ} \mathrm{C}$ for 60 minutes after digestion with Hind III and EcoRI, respectively. The radiolabelled riboprobes were purified by phenol chloroform extraction and centrifugation through a Bio-Spin 30 chromatography column (Bio-Rad Laboratories, Hercules, California, USA) to exclude unincorporated nucleotides of $\left[{ }^{35} \mathrm{~S}\right] \alpha \mathrm{UTP}$.

\section{IN SITU HYBRIDISATION}

The methods used for in situ hybridisation were modified from those described by Adachi et al. ${ }^{19}$ Frozen sections ( $5 \mu \mathrm{m}$ thick) were cut at $-20^{\circ} \mathrm{C}$ and fixed with $4 \%$ paraformaldehyde in PBS ( $\mathrm{pH} \mathrm{7.4)}$ for 10 minutes at room temperature. The slides were washed twice in $2 \times$ SSC ( $150 \mathrm{mM}$ sodium chloride, $15 \mathrm{mM}$ sodium citrate, $\mathrm{pH} 7 \cdot 0$ ), immersed in $0.1 \mathrm{M}$ triethanolamine buffer $(\mathrm{pH} 8.0)$ for two minutes, and incubated in $0.25 \%$ acetic anhydride in the same buffer for 10 minutes. The slides were then washed in $2 \times \mathrm{SSC}$, in PBS, immersed in $0 \cdot 1 \mathrm{M}$ Tris- $\mathrm{HCl}(\mathrm{pH} \mathrm{7.0)}$ containing $0 \cdot 1 \mathrm{M}$ glycine for 30 minutes, and rinsed several times in $2 \times$ SSC. After predigestion with proteinase $\mathrm{K}\left(1 \mathrm{mg} / \mathrm{ml}\right.$ in $\mathrm{PBS}$ at $37^{\circ} \mathrm{C}$ for five mintes), the samples were washed in PBS containing $2 \mathrm{mg} / \mathrm{ml}$ glycine, postfixed in $4 \%$ paraformaldehyde in PBS for five minutes, and again washed twice in the same buffer.

Prehybridisation was performed on slides with a hybridisation mixture which contained $2 \times$ SSC, $50 \%$ formamide, $1 \times$ Denhardt's solution (Sigma, St Louis, Missouri, USA), $10 \mathrm{mM}$ DTT, $1 \mathrm{mg} / \mathrm{ml}$ yeast tRNA, $100 \mu \mathrm{g} / \mathrm{ml}$ of heat denatured salmon sperm DNA, and $2.5 \mathrm{mM}$ EDTA in $50 \mathrm{mM}$ phosphate buffer $(\mathrm{pH} 6 \cdot 8)$ at $50^{\circ} \mathrm{C}$ for three hours in a humidified chamber. Hybridisation was carried out with the labeled riboprobe $\left(5 \times 10^{5} \mathrm{cpm} /\right.$ slide $)$ in the hybridisation mixture with $10 \%$ dextran sulphate (Sigma) at $50^{\circ} \mathrm{C}$ for 12 hours. After hybridisation the slides were immersed in $50 \%$ formamide- $2 \times$ SSC containing $10 \mathrm{mM}$ DTT at $45^{\circ} \mathrm{C}$ for 30 minutes, washed in $2 \times \mathrm{SSC}$, and incubated in RNase solution $(100 \mathrm{mg} / \mathrm{ml}$ RNase A [Sigma], $1 \mu \mathrm{g} / \mathrm{ml}$ RNase T1 [Boehringer Mannheim]) at $37^{\circ} \mathrm{C}$ for 30 minutes. The slides were subsequently washed twice in $50 \%$ formamide $-2 \times \mathrm{SSC}$ at $45^{\circ} \mathrm{C}$, rinsed with $2 \times$ SSC and distilled water, and dehydrated sequentially in $70 \%, 80 \%$, and $90 \%$ ethanol, then dried in air. Autoradiography was performed by dipping in Konica autoradiographic emulsion (Type NR-M2, silver grain size $0 \cdot 15 \mu \mathrm{m}$, Konica Corp, Tokyo, Japan) diluted $1: 1$ with $1 \mathrm{M}$ sodium acetate at $42^{\circ} \mathrm{C}$. After three days exposure at $4^{\circ} \mathrm{C}$ the slides were developed and fixed at $25^{\circ} \mathrm{C}$. The developed slides were stained with haematoxylin and eosin. Non-specific hybridisation was determined by parallel incubation of an adjacent section with ${ }^{35} \mathrm{~S}$-labelled sense CEA riboprobe.

To quantify the relative number of CEA mRNA transcripts per cell (nucleus), silver grains hybridised with ${ }^{35} \mathrm{~S}$-labelled antisense CEA riboprobe were counted in an average of 100 cells (nuclei) for each sample. ${ }^{20}$ The counts were corrected by subtracting the non-specific hybridisation with the CEA sense riboprobe. The value was represented as average numbers of grains per cell.

CHEMOTAXIS OF NEUTROPHILS AND MONOCYTES Neutrophils and monocytes were purified from peripheral blood of five non-smoking individuals by the methods of Aalto et al and Iwabuchi et al, respectively. ${ }^{2122}$ Purity of monocytes was examined by $\alpha$-naphthyl acetate esterase staining (Sigma Diagnostics, St Louis, Missouri, USA). Both neutrophil and monocyte populations were greater than $95 \%$. Viability as assessed by trypan blue dye exclusion was greater than $95 \%$ for both cell types. Chemotaxis for neutrophils and monocytes was assayed by the method of Zigmond and Hirsh with a minor modification employing a Boyden chamber with a cellulose nitrate membrane. ${ }^{23}$ The pore size of the membrane was $3 \mu \mathrm{m}$ for neutrophils and $5 \mu \mathrm{m}$ for monocytes. Varying concentrations of purified human CEA (Gelco Diagnostics Inc, Shreveport, Louisiana, USA) in PBS supplemented with $1 \mathrm{mM} \mathrm{Ca}{ }^{2+}, \mathrm{Mg}^{2+}$, and $10 \%$ BSA (Fraction V, Sigma) were added to the lower wells of the chamber. One million neutrophils or $6.5 \times 10^{5}$ monocytes in $300 \mu \mathrm{l}$ PBS were placed into each of the upper wells. The entire apparatus was incubated at $37^{\circ} \mathrm{C}$ for 45 minutes for neutrophils and 30 minutes for monocytes. The membrane was then fixed with neutral buffered formalin for 30 minutes and stained with Mayer's haematoxylin. With a $40 \times$ objective the distance $(\mu \mathrm{m})$ from the top of the filter to the furthest two cells at the same focal plane was measured with a micrometer on a fine focus adjuster. This measure was taken for 10 fields across the filter. Chequered 
Figure 1 CEA content (ng/mg protein) in normal human lung tissue from five non-smokers (four with lung cancer, one with non-carcinomatous disease), five ex-smokers with lung cancer, nine smokers with lung cancer, and five smokers with noncarcinomatous disease $(p<0.05$ for smokers with cancer versus non-smokers or ex-smokers, and for smokers with noncarcinomatous disease versus non-smokers or ex-smokers).

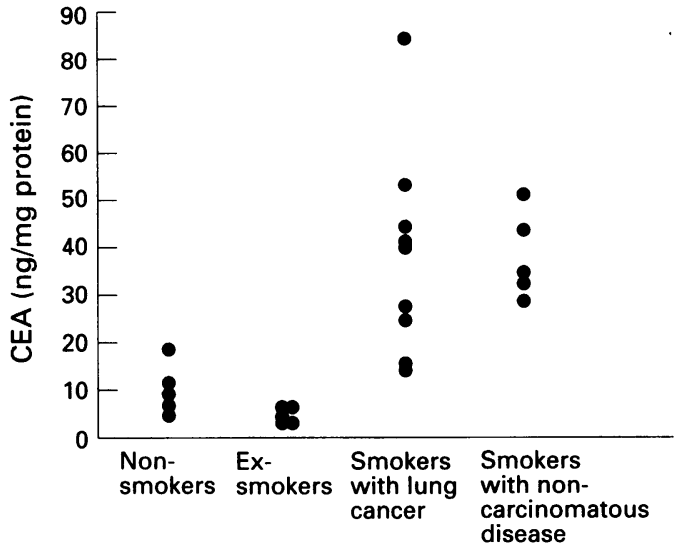

board analysis of neutrophil motility was conducted according to the method of Zigmond and Hirsh. ${ }^{23}$ Varying concentrations of the authentic CEA were added to the upper and lower wells of the apparatus. Chemotaxis occurs when there is a positive gradient of chemoattractant. Chemokinetic motility occurs even when the chemoattractant is present at equivalent concentrations in both upper and lower chambers. We used FMLP at a concentration of $10^{-8} \mathrm{M}$ as a positive control for neutrophil and monocyte chemoattractance. ${ }^{24}$

\section{DATA ANALYSIS}

Data are presented as mean (SD). Comparisons in CEA assay and number of silver grains between carcinomatous tissues and noncarcinomatous tissues were made by the two tailed $t$ test. Other comparisons between groups were made by one way ANOVA. A probability of $<0.05$ was considered significant.

\section{Results}

CEA EXPRESSION IN NON-CARCINOMATOUS LUNG PARENCHYMAL TISSUES

The mean (SD) CEA content of lung tissue homogenates obtained from normal lung was $11.0(5.4) \mathrm{ng} / \mathrm{mg}$ protein for non-smokers, 5.9 $(2 \cdot 2)$ for ex-smokers, $38.2(21.6)$ for smokers with NSCLC, and $38.0(9.2)$ for smokers with non-carcinomatous disease (fig 1). The level for smokers with either NSCLC or non-carcinomatous disease was significantly higher than that for non-smokers or ex-smokers $(p<0.05)$. The result was comparable with previous data obtained in BAL fluid samples. ${ }^{6}$

To examine the localisation of production of CEA in normal lung tissue we performed in situ hybridisation using a CEA-specific riboprobe. A rather diffuse hybridisation signal was observed along the alveolar wall, indicating that CEA mRNA was expressed in the alveolar epithelial cells and also possibly in capillary endothelial cells, pulmonary fibroblasts, or other interstitial cells (fig $2 \mathrm{~A}, \mathrm{~B}, \mathrm{C}$ ). The hybridisation signal was also observed in bronchiolar tissue (data not shown). The mean numbers of grains/cell in the alveolar tissues were $3.1(0.6)$ in non-smokers, $4.0(1.7)$ in exsmokers, $14.0(8.4)$ in smokers with NSCLC, and $11.2(4 \cdot 1)$ in smokers with non-carcinomatous disease, respectively (fig 3 ). The value for smokers with non-carcinomatous disease was not different from that for smokers with NSCLC $(p>0 \cdot 1)$, but significantly higher than that for non-smokers or ex-smokers ( $p<0.05$ for each comparison). There was no difference in CEA expression between the necropsy and surgical materials.

\section{CEA EXPRESSION IN CARCINOMATOUS TISSUES}

The CEA content in carcinomatous tissue was $42.8(37.3) \mathrm{ng} / \mathrm{mg}$ protein for non-smokers, $38 \cdot 2(42 \cdot 2)$ for ex-smokers, and $59 \cdot 0(22 \cdot 5)$ for smokers. The CEA content in carcinomatous tissues was significantly higher than that of non-carcinomatous tissues $(p<0.05)$. However, there is no difference among non-smokers, exsmokers, and smokers in CEA content of carcinomatous tissues. CEA mRNA expression was significantly higher in lung cancer tissue compared with non-carcinomatous tissue (fig 2D). The numbers of grains per cell in carcinomatous tissue were significantly higher than that of non-carcinomatous tissues $(\mathrm{p}<0.05)$ but were not different among the non-smokers (30.3 (3.9)), ex-smokers (38.3 $(13 \cdot 8))$, and smokers $(44 \cdot 3(5 \cdot 2))$.

\section{INDUCTION OF CEA EXPRESSION BY}

\section{STIMULATION WITH CIGARETTE SMOKE}

The cell lines that originated from human fetal lung were stimulated with the medium exposed to cigarette smoke to examine the effect of cigarette smoke on CEA expression in these cells. Since the CEA content of the cell lysate and supernatant were too small to measure by EIA, we compared CEA mRNA expression by in situ hybridisation. The expression of CEA mRNA transcripts in IMR-90, MRC-9, and CCD14Br was upregulated after the stimulation, while the expression did not change after incubation with air-treated medium (figs 4 and 5). Maximum mRNA expression was observed at nine hours for IMR-90, six hours for MRC-90, and 24 hours for CCD-14Br, respectively. The average numbers of grains per cell following incubation with medium exposed to cigarette smoke at 0 hours and peak time points were $5.1(1.6)$ and $9.2(1.5)$ for IMR-90; $5.8(1 \cdot 1)$ and $11.2(1.6)$ for MRC-9; and $5 \cdot 1(1.0)$ and $12.5(2.4)$ for CCD-14Br, respectively (fig 5) $(p<0.05$ for each comparison).

CHEMOTAXIS OF NEUTROPHILS AND MONOCYTES TO AUTHENTIC CEA

The chemotaxis of neutrophils and monocytes to authentic CEA was analysed by a modified Boyden chamber technique. The chemotaxis of neutrophils to CEA was dose dependent in a range from 0 to $50 \mathrm{ng} / \mathrm{ml}$. The average distance $(\mu \mathrm{m})$ of cell movement for neutrophils was 16.6 $(6 \cdot 5), 27 \cdot 3(7 \cdot 3), 51 \cdot 9(20 \cdot 7)$, and $38 \cdot 4(17 \cdot 8)$ at concentrations of $0,10,50$, and $100 \mathrm{ng} / \mathrm{ml}$ of authentic CEA in the lower well, respectively ( $p<0.05$ for each concentration versus negative control) (fig 6A). Chemoattractant activity at the concentration of $50 \mathrm{ng} / \mathrm{ml}$ CEA was comparable to that of $10^{-8} \mathrm{M}$ FMLP. Chemotactic 

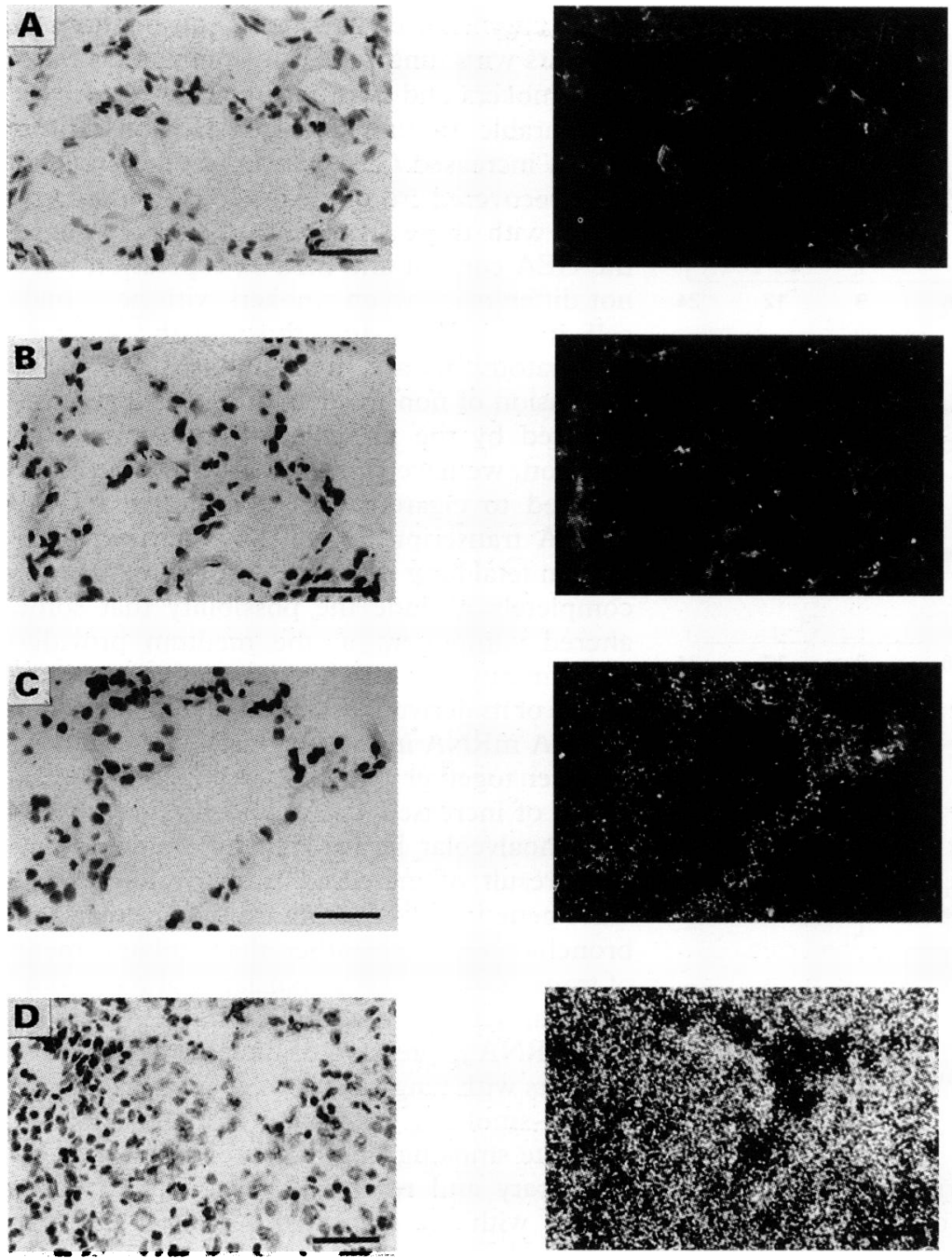

Figure 2 Examples of in situ hybridisation to demonstrate CEA mRNA in noncarcinomatous lung tissue and cancer tissue. Panels on the left are bright field photomicrographs and those on the right are corresponding areas of dark field photomicrographs hybridised with antisense CEA riboprobe. (A) normal alveolar tissue from a non-smoker with lung cancer; (B) normal alveolar tissue from an ex-smoker with lung cancer; (C) normal alveolar tissue from a smoker with lung cancer; (D) carcinoma tissue from a patient with non-small cell carcinoma of the lung. Note that CEA mRNA transcripts were found along the alveolar walls $(A, B, C)$ and cancer cells $(D)$ hybridised with antisense CEA riboprobe. Messenger $R N A$ expression seemed to be enhanced in the alveolar tissue of the smoker compared with that of a non-smoker and an ex-smoker. Considerably higher expression per tumour cell was observed in the carcinomatous tissue. Bar $=300 \mu \mathrm{m}$.

Figure 3 Comparison of silver grain numbers in non-carcinomatous lung tissue obtained from five non-smokers, five exsmokers, nine smokers with lung cancer, and five smokers with noncarcinomatous disease using in situ hybridisation with $C E A$ specific riboprobe $(p<0.05$ for non-smokers versus smokers with lung cancer or benign disease). response was not observed in the experiments using monocytes (fig 6B). Chequered board analysis using the same concentration of CEA in both upper and lower wells showed that chemokinetic movement of neutrophils in the presence of CEA was not enhanced at higher



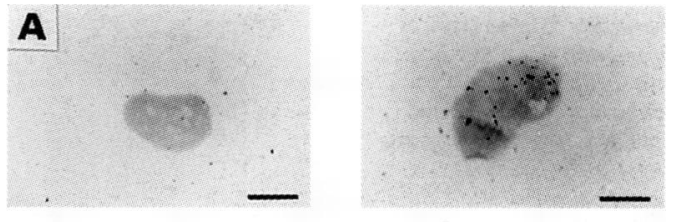

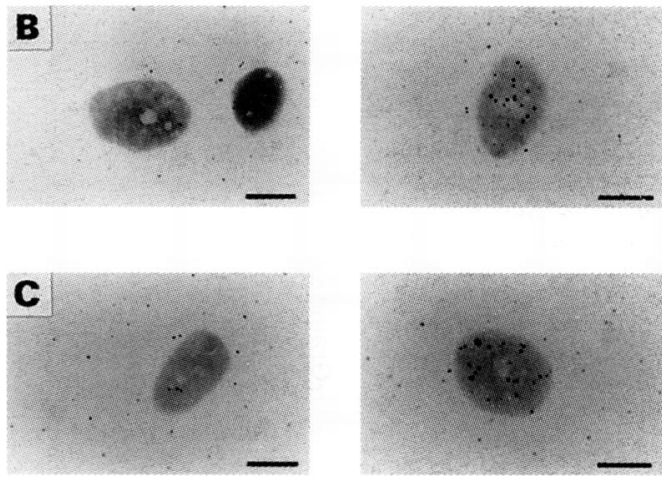

Figure 4 In situ hybridisation to detect CEA mRNA in fetal lung cell lines stimulated by cigarette smoke-treated medium. $(A),(B)$, and $(C)$ represent bright field photomicrographs of examples from the human fetus lung cell lines IMR-90, MRC-9, and CCD-14Br, respectively. Panels on the left are photomicrographs of cells treated with air-exposed medium, panels on the right are photographs of cells at peak time point (at 9 hours for IMR-90, 6 hours for MRC-9, and 24 hours for $C C D-14 B r$ ), respectively, following smoke treatment. Note that CEA $m R N A$ expression in each cell line appears to be increased by cigarette smoke-treated medium. Bar $=60 \mu \mathrm{m}$.

CEA concentrations (fig 6A). These results suggest that neutrophil response to CEA represented a gradient-directed migration (chemotaxis) rather than enhanced random cell movement (chemokinesis).

\section{Discussion}

CEA is a $180 \mathrm{kDa}$ oncofetal glycoprotein that is highly concentrated in fetal tissues and in a number of tumour cells. The plasma CEA concentration was used initially as a tumour marker to screen for the presence of tumour, but its sensitivity was not sufficient to make it a reliable test. ${ }^{5}$ Later, CEA was found on the epithelial cell surface of various organs, including colon, uterus, and lung. ${ }^{89}$ The presence of CEA in alveolar and bronchial epithelial cells has been shown by immunohistochemical studies and the protein has been found in BAL fluid. ${ }^{41011}$ Either local production or preferential transport from the circulation via receptor-mediated endocytosis may account for the higher concentration of CEA in bronchial secretions than plasma. ${ }^{91225}$ The present study demonstrated CEA mRNA expression in alveolar and bronchiolar tissues by in situ hybridisation. This finding suggests local production of CEA protein in the lower respiratory tract. Although the result does not exclude the possibility of active transport of CEA from the circulation or decreased clearance of CEA, it is likely that the major source of CEA in the lung is local production by bronchoalveolar cells.

In the present study a hybridisation signal specific to CEA was obtained along the alveolar wall. Although the exact identification of the 
Figure 5 Comparison of silver grain numbers in three cell lines after exposed to air and cigarette smoke at different additional incubation time points. (A) IMR-90; (B) $M R C-9 ;(C) C C D-14 B r$ The average numbers of silver grains per cell treated with air-exposed medium

(O) were $5.0(0.2)$ in IMR-90, $4.9(0.4)$ in $M R C-9$, and $5 \cdot 1(0 \cdot 6)$ in $C C D-14 B r$. The values with cigarette smokeexposed medium ( $\bigcirc$ ) at 0 hours and peak time points were $5 \cdot 1(1 \cdot 6)$ and $9 \cdot 2$ $(1 \cdot 5)$ at 9 hours in $I M R$ $90,5 \cdot 8(1 \cdot 1)$ and $11 \cdot 2$ $(1 \cdot 6)$ at 6 hours in MRC9 , and $5 \cdot 1(1 \cdot 0)$ and $12 \cdot 5$ $(2 \cdot 4)$ at 24 hours in $C C D-14 B r{ }^{*} p<0.05$ for each comparison with 0 hours incubation with smoke-treated medium. incubation with medium
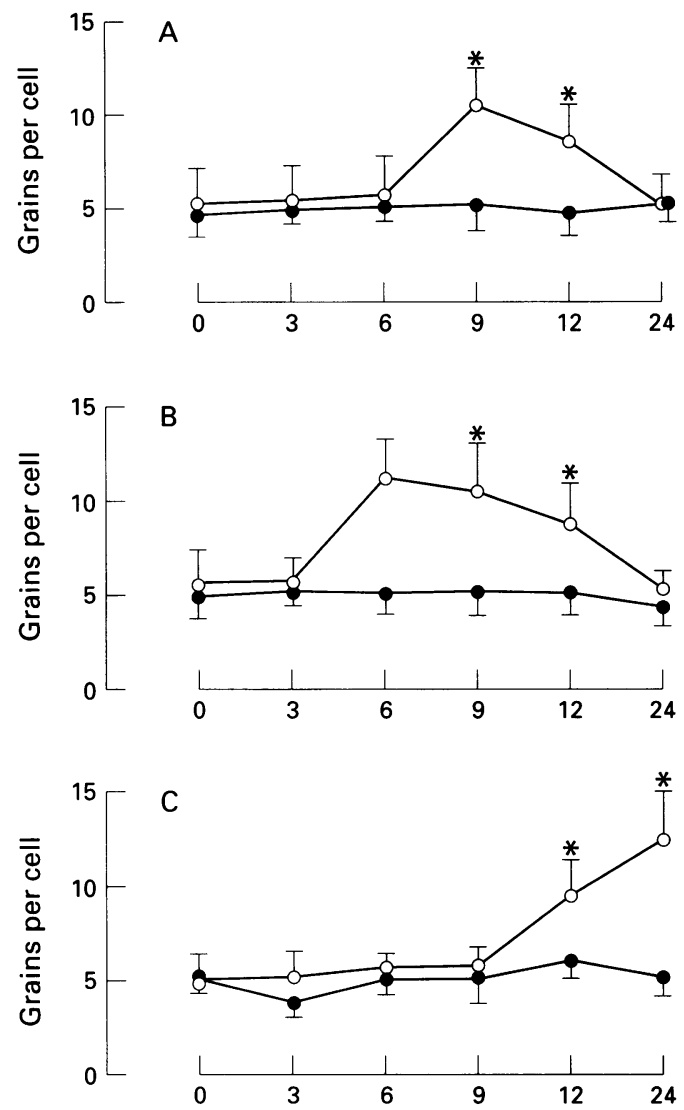

Additional incubation time (hours)

cell type labelled by the riboprobe is difficult, we believe that the CEA mRNA expression is in alveolar and bronchiolar epithelial cells since a strong signal was observed along the bronchioloalveolar surface. However, we cannot exclude the possibility that capillary endothelial cells or pulmonary fibroblasts expressed CEA mRNA transcripts from our present data.

We have shown that both the CEA content and mRNA expression in the lung tissue of cigarette smokers with non-carcinomatous dis-

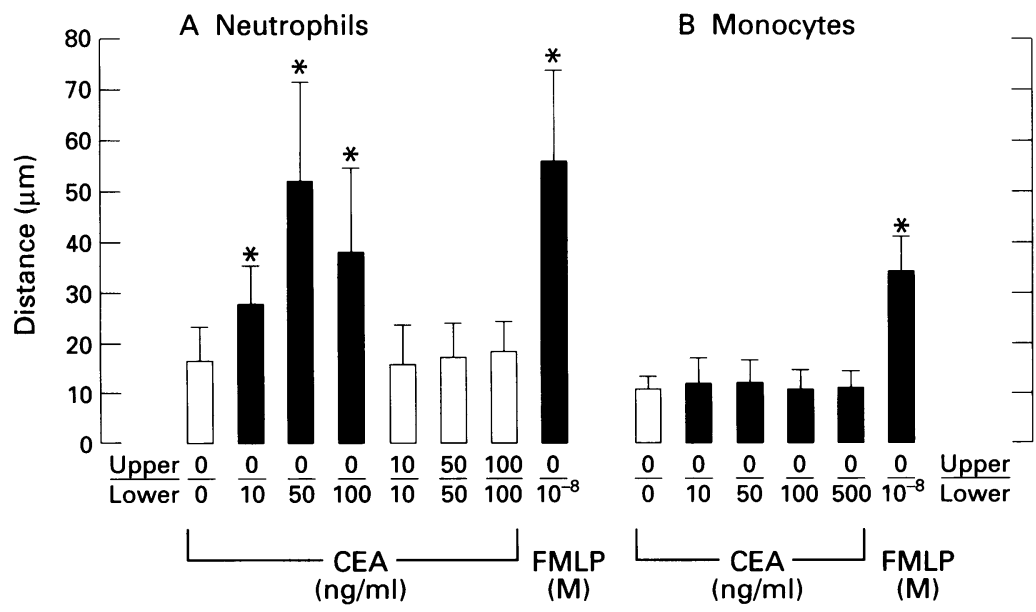

Figure 6 Chemotaxis and chemokinesis of neutrophils and monocytes to purified CEA expressed as concentrations of CEA ( $\mathrm{ng} / \mathrm{ml})$ in upper and lower wells of the chambers versus distance $(\mu \mathrm{m})$ of cell migration. $(A)$ Chemotaxis of neutrophils in response to $C E A$ was shown at concentrations of $10-100 \mathrm{ng} / \mathrm{ml}$, with an optimal concentration at $50 \mathrm{ng} / \mathrm{ml}$ (solid bar). Chemokinesis of neutrophils was not observed at concentrations of 10-100 ng/ $m l$ (open bar). (B) Chemotaxis of monocytes to $C E A$ was not observed at concentrations $m l$ (open bar). (B) Chemotaxis of monocytes to CEA was not observed at concentration
of $10-500 \mathrm{ng} / \mathrm{ml}$. Stimulation of FMLP $\left(10^{-8} \mathrm{M}\right)$ was used as a positive control for chemotaxis of both neutrophils and monocytes. ${ }^{*} p<0.05$ compared with negative control. ease were increased as much as in the lungs of smokers with lung cancer by comparison with non-smokers and ex-smokers. This result was comparable to previous studies which have shown increased CEA concentrations in BAL fluid recovered from "healthy" smokers compared with those from non-smokers. ${ }^{4-7}$ Since the CEA content and mRNA expression were not different between smokers with non-small cell lung cancer and those with non-carcinomatous disease, it is unlikely that CEA expression of non-involved lung tissue was influenced by the presence of the tumour. In addition, we have shown that culture medium exposed to cigarette smoke stimulated CEA mRNA transcripts in cell lines derived from human fetal lung in vitro. Although we cannot completely exclude the possibility that some altered component in the medium provides the stimulus, this result suggests that cigarette smoke or its derivatives stimulate the expression of CEA mRNA in the lung cells.

Taken together with in situ studies, the mechanism of increased CEA concentration in the bronchoalveolar lavage fluid of smokers may be a result of increased transcription of the CEA gene in cells making up the alveolar and bronchiolar tissues rather than enhancement of translational or post-translational regulation of this antigen. ${ }^{26}$ Interestingly, the CEA content and mRNA expression of lung tissue from exsmokers with lung cancer were similar to those of non-smokers, suggesting that the effect of cigarette smoking on CEA expression may be temporary and reversible. This is also compatible with the clinical observation that the increased serum CEA concentration rapidly returned to the normal level after the cessation of cigarette smoking, although the true source of serum CEA in smokers is not known. ${ }^{27}$

The CEA content and mRNA expression in carcinomatous tissue were higher than those in non-carcinomatous tissue irrespective of smoking history. This suggests that CEA expression in cancer cells appears to need further regulation by some mechanism other than cigarette smoking.

CEA expression has been considered to be a marker of chronic inflammation or malignant transformation in the lower respiratory tract. However, the functions and significance of this antigen for malignant transformation remain unknown. Recent studies have revealed that CEA functions as a $\mathrm{Ca}^{2+}$ independent homophilic cell adhesion molecule as well as a heterophilic adhesion molecule to non-specific crossreacting antigens which are usually expressed in neutrophils. ${ }^{28-34}$ In addition, we found that CEA may function as a chemoattractant for neutrophils in vitro. Maximum chemoattractant activity was observed at a concentration of $50 \mathrm{ng} / \mathrm{ml}$ which was comparable with the CEA concentration of epithelial lining fluid obtained from smokers by bronchoalveolar lavage. ${ }^{4}$ Furthermore, the maximum chemoattractant activity of CEA was similar to that of FMLP at a concentration of $10^{-8} \mathrm{M}$, which is equivalent to effective chemoattractant concentrations of leukotriene $\mathrm{B}_{4}$ or interleukin $8 .^{36}$ Thus, CEA expressed in the 
bronchioloalveolar tissue of smokers may contribute to the recruitment of neutrophils into lung tissue and air spaces through its chemoattractant activity and heterophilic cell adhesion activity. However, the present study does not exclude the importance of other mechanisms of neutrophil recruitment into the lower respiratory tract in cigarette smokers. Several mechanisms of neutrophil recruitment have been proposed by various investigators. Activated complement, leukotriene $B_{4}$, and interleukin 8 are potent chemoattractants for neutrophils in addition to other factors released from alveolar macrophages. ${ }^{13536}$ Another mechanism for the influx of neutrophils may be related to increased Gc globulin-mediated chemoattractive activity in the lungs of smokers. ${ }^{37}$

In summary, we have shown that the CEA content and mRNA expression in the lungs of smokers were increased compared with nonsmokers and ex-smokers. We have also shown that medium exposed to cigarette smoke increases CEA mRNA expression in various cell lines derived from human fetal lung. Although the biological significance of CEA in human lung is still not known, we suggest that CEA may possibly function to recruit neutrophils into the lung.

The authors wish to thank the Japanese Cancer Research Resources Bank (JCRB) for providing the cell lines. This study was supported by a research grant from the Smoking Research Foundation of Japan.

1 Hunninghake GW, Crystal RG. Cigarette smoking and lung destruction. Am Rev Respir Dis 1983;128:833-8.

2 Niewoehner DE, Klernerman J, Rice DB. Pathologic changes in the peripheral airways of young cigarette smokers. $N$ Engl $\mathscr{f}$ Med 1974;291:755-8.

3 Auerback O, Garfunkel L, Hammond EC. Relationship of smoking and age to findings in the lung parenchyma: a microscopic study. Chest 1974;65:29-35.

4 Takahashi H, Nukiwa T, Matsuoka R, Danbara T, Natori H, Arai $\mathrm{T}$, et al. Carcinoembryonic antigen in bronchoalveolar lavage fluid in patients with idiopathic pulmonary fibrosis. fpn $\mathcal{F}$ Med 1985;24:36-43.

5 Wesselius LJ, Dark DS, Papasian CJ. Airway carcinoembryonic antigen concentrations in patients with central lung cancer or chronic bronchitis. Chest 1990;98: central

6 Merrill WW, Goodman M, Matthay RA, Naegel GP, Vandevoorde JP, Myl AD, et al. Quantitation of carcinoembryonic antigen in the lung fluid of normal smokers and nonsmokers. Am Rev Respir Dis 1981;123:29-31.

7 de Diego A, Compte L, Sanchis J, Enguidanos MJ. Usefulness of carcinoembryonic antigen determination in bronchoalveolar lavage fluid. A comparative study among patients with peripheral lung cancer, pneumonia, and healthy individuals. Chest 1991;100:1060-3.

8 Thompson JA, Grunert F, Zimmerman W. Carcinoembryonic antigen gene family: Molecular biology and clinical perspectives. F Clin Lab Anal 1991;5:344-66.

9 Thomas P, Toth CA, Saini KS, Jessup JM, Steel G. The structure, metabolism and function of the carcinoembryonic antigen gene family. Biochim Biophys Acta 1990;1032:177-89.

10 Tsutsumi Y, Onoda N, Misawa M, Kuroki M, Matsuoka Y. Immunohistochemical demonstration of nonspecific cross-reacting antigen in normal and neoplastic human tissues using a monoclonal antibody. Acta Pathol fpn 1990; 40:85-7.

11 Nouwen EJ, Pollet DE, Eerdekens MW, Hendrix PG, Briers TW, De Broe ME. Immunohistochemical localization of placental alkaline phosphatase, carcinoembryonic antigen, and cancer antigen 125 in normal and neoplastic human lung. Cancer Res 1986;46:866-76.

12 Stockley RA, Shaw J, Whitfield AGW, Whitehead TP, Clarke CA, Burnett D. Effect of cigarette smoking, pulmonary inflammation, and lung disease on concentrations of carcinoembryonic antigen in serum and sercretions. Thorax 1986;41:17-24.
13 Lowry OH, Rosebrough NJ, Farr AL, Randall RJ. Protein measurement with the Folin phenol reagent. $\mathcal{F}$ Biol Chem 1951;193:265-75.

14 Ohwada A, Takahashi $\mathrm{H}$, Uchida $\mathrm{K}$, Nukiwa T, Kira S Gene analysis of heterozygous protein $\mathrm{C}$ deficiency in a patient with pulmonary arterial thromboembolism. $A m$ Rev Respir Dis 1992;145:1491-4.

15 Shimada S, Ogawa M, Schlom J, Greiner JW. Identification of a novel tumor-associated Mr 110,000 gene product in human gastric carcinoma cells that is immunologically related to carcinoembryonic antigen. Cancer Res 1991;51 5694-703

16 Oikawa S, Nakazato H, Kosaki G. Primary structure of human carcinoembryonic antigen (CEA) deduced from cDNA sequence. Biochem Biophys Res Commun 1987;142: 511-8.

17 Zimmermann W, Ortlieb B, Friedrich R, von Kleist S Isolation and characterization of cDNA clones encoding the human carcinoembryonic antigen reveal a highly conserved repeating structure. Proc Natl Acad Sci USA 1987; 84:2960-4.

18 Sambrook J, Fritsch E, Maniatis T. Molecular cloning: laboratory manual. 2nd edn. Cold Spring Harbor: Cold Spring Harbor Laboratory Press, 1989:1.21-1.85.

19 Adachi K, Yamauchi K, Bernaudin J-F, Fouret P, Ferran VJ, Crystal RG. Evaluation of fibronectin gene expression by in situ hybridization. Am ₹ Pathol 1988;133:193-203.

20 Mak JC, Baraniuk JN, Barnes PJ. Localization of muscarinic receptor subtype mRNAs in human lung. Am $\mathcal{f}$ Respir Cell Mol Biol 1992;7:344-8.

21 Aalto M, Kulonen E, Ronnemaa T, Sundstrom C, Vilpo $\mathrm{J}$. Liberation of a fibrogenic factor from human blood monocytes, ascites cells, cultured histiocytes and transformed mouse macrophages by treatment with $\mathrm{SiO}_{2}$. Scand f Clin Lab Invest 1980;40:311-8.

22 Iwabuchi K, Yamshita T. Platelet-derived neutrophil adherence-inhibiting factor in humans. Blood 1990;76:236873.

23 Zigmond SH and Hirsch JG. Effects of cytochalasin B on polymorphonuclear leukocyte locomotion, phagocytosis and glycolysis. Exp Cell Res 1972;73:383-93.

24 Schiffmann E, Corcoran BA, Wahl SM. N-formylmethionyl peptides as chemoattractants for leukocytes. Proc Nat Acad Sci USA 1975;72:1059-62.

25 Toth CA, Thomas P, Broitman SA, Zamcheck N. Receptormediated endocytosis of carcinoembryonic antigen by rat liver Kupper cells. Cancer Res 1985;45:392-7.

26 Boucher D, Cournoyer D, Stanners CP, Fuks A. Studies on the control of gene expression of the carcinoembryonic antigen family in human tissue. Cancer Res 1989;49:84752.

27 Clarke C, Hine KR, Dykes PW, Whitehead TP. Carcinoembryonic antigen and smoking. $\mathcal{f} R$ Coll Phys Lond 1980;14:227-8.

28 Benchimol S, Fuks A, Jothy S, Beauchemin N, Shirota K Stanners CP. Carcinoembryonic antigen, a human tumo marker, functions as an intercellular adhesion molecule. Cell 1989;57:327-34

29 Oikawa S, Inuzuka C, Kuroki M, Matsuoka Y, Kosaki G, Nakazato $H$. Cell adhesion activity of non-specific crossreacting antigen (NCA) and carcinoembryonic antigen (CEA) expressed on CHO cell surface: homophilic and heterophilic adhesion. Biochem Biophys Res Commun 1989; 164:39-45.

30 Kuroki M, Matsuo Y, Kuroki M, Matsuoka Y. Nonspecific cross-reacting antigen (NCA) expressed by human granulocytes: Six species with different peptide sizes and membrane anchoring forms. Biochem Biophys Res Commun 1990;166:701-8.

31 Kuroki M, Arakawa F, Matsuo Y, Oikawa S, Misumi Y, Nakazato $\mathrm{H}$, et al. Molecular cloning of nonspecific crossreacting antigens in human granulocytes. $\mathcal{F}$ Biol Chem 1991;266:11810-7.

32 Ducker TP, Skubitz KM. Subcellular isolation of CD66, CD67, and NCA in human neutrophils. F Leukoc Biol 1992;52:11-6.

33 Audette M, Buchegger F, Schreyer M, Mach J-P. Monoclonal antibody against carcinoembryonic antigen (CEA) identifies two new forms of crossreacting antigens of molecular weight 90,000 and 160,000 in normal granulocytes. Mol Immunol 1987;24:1177-86.

44 Oikawa S, Inuzuka C, Kuroki M, Arakawa F, Matsuoka Y, Kosaki G, et al. A specific heterotypic cell adhesion activity between members of carcinoembryonic antigen family, W272 and NCA, is mediated by $\mathrm{N}$-domains. $\mathscr{F}$ Biol Chem 1991;266:7995-8001.

35 Robbins RA, Nelson KJ, Gossman GL, Koyama S, Rennar SI. Complement activation by cigarette smoke. Am Physiol 1991;260:L254-9.

36 Harkin DG, Bignold LP. Neutrophil polarisation in plasm differs to that induced by endogenous chemoattractants with regard to frequency of uropod formation and requirement for divalent cations. Cell Biol Int 1994;18:177 87.

37 Metcalf JP, Thompson AB, Gossman GL, Nelson KJ, Koy ama S, Rennard SI, et al. Gc globulin functions as cochemotaxin in the lower respiratory tract. A potential mechanism for lung neutrophil recruitment in cigarette smokers. Am Rev Respir Dis 1991;143:844-9. 